\title{
Regulation of steroid synthesis and apoptosis by insulin-like growth factor I and insulin-like growth factor binding protein 3 in human corpus luteum during the midluteal phase
}

\author{
A. Villavicencio ${ }^{1}$, G. Iñiguez ${ }^{1}$, M. C. Johnson ${ }^{1}$, \\ F. Gabler ${ }^{2}$, A. Palomino ${ }^{1}$ and M. Vega ${ }^{1 *}$ \\ ${ }^{1}$ Institute of Maternal and Child Research and ${ }^{2}$ Pathology Department, \\ San Borja-Arriarán Clinical Hospital, School of Medicine, University of Chile
}

The aim of the present study was to investigate the action of insulin-like growth factor I (IGF-I) and insulin-like growth factor-binding protein 3 (IGFBP-3) on steroidogenesis and apoptosis in human corpus luteum during the midluteal phase. Slices from corpora lutea were incubated for $4 \mathrm{~h}$ with IGF-I or IGFBP-3. Progesterone, oestradiol, androstenedione and testosterone concentrations were determined by radioimmunoassay; caspase 3 expression was assessed by immunohistochemistry; bcl-2, bax and $\boldsymbol{P}_{\text {450arom }}$ expression were assessed by RT-PCR; and apoptosis was detected by in situ terminal deoxynucleotidyl transferase-mediated dUTP nick-end labelling. The results showed that addition of IGF-I stimulated progesterone production $(150 \%, P<0.01)$, oestradiol production $(65 \%$, $P<0.05$ ) and $b c l-2$ gene expression (approximately $200 \%$, $P<0.05)$, but decreased apoptosis $(P<0.05)$. In contrast, IGFBP-3 reduced steroid production and increased bax gene expression and the percentage of apoptotic cells $(P<0.05)$. Neither IGF-I nor IGFBP-3 had an effect on $\boldsymbol{P}_{450 \text { arom }}$ expression or on the concentrations of its substrates. However, maximum expression of caspase 3 was detected in corpus luteum during the midluteal phase. In conclusion, these results indicate that IGF-I and IGFBP-3 act as regulatory peptides of the function of the human corpus luteum during the midluteal phase. This action may be direct or mediated by steroid production or by bcl-2-bax expression.

\section{Introduction}

The human corpus luteum is an endocrine gland of transient feature in a non-fertile cycle, which has recognizable stages of growth, maximum development and involution. The cell composition of the corpus luteum (Lei et al., 1991; Bukovsky et al., 1995; Carrasco et al., 1996) and its secreted compounds contribute to the rapid development, maturity and regression of the corpus luteum.

Several molecules act as intraovarian regulators of the lifespan of the human corpus luteum, including cytokines, growth factors, reactive oxygen species (Vega et al., 1995; Johnson et al., 1996, 1999; Brannstrom et al., 1999), peptide hormones, steroids (Vega et al., 1994a) and members of the Bcl-2 family (Rodger et al., 1995, 1998; Sugino et al., 2000). Maximum steroidogenic activity in the corpus luteum occurs during the midluteal phase, as evidenced by progesterone and oestradiol production, and, thereafter, a gradual decline in steroid synthesis occurs, representing the involution period of the corpus luteum (Vega et al., 1994b).

Insulin-like growth factor I (IGF-I), IGF-II, IGF receptor type 1 (RIGF-1) and IGF-binding proteins 1-6 (IGFBP-1-6)

${ }^{*}$ Correspondence: P.O. Box 226-3, IDIMI, University of Chile, Santiago, Chile

Email: mvega@machi.med.uchile.cl are present in the human corpus luteum throughout the luteal phase (Iñiguez et al., 2001). However, IGFBP-3 is the most abundant circulating binding protein for IGFs (Drop et al., 1992). IGF-I regulates human luteal steroidogenesis in a cell culture system by an increase in progesterone (Devoto et al., 1995) and oestradiol production (Johnson et al., 1996). Furthermore, IGF-I has an important anti-apoptotic effect in various tissues (Morales et al., 2000; Remacle et al., 2000) and regulates the relative concentrations of some members of the Bcl-2 family (Dews et al., 2000).

Several authors have suggested that luteal regression in many species, including humans (Shikone et al., 1996; Vega et al., 2000), occurs by programmed cell death or apoptosis. Addition or withdrawal of steroid hormones from target tissues may induce apoptosis (Rotello et al., 1992; Tenniswood et al., 1992). In addition, oestradiol exerts an anti-apoptotic effect in several tissues and cell lines (Gompel et al., 2000; Razandi et al., 2000), although it is not known whether oestradiol exhibits an anti-apoptotic action in the human corpus luteum. However, the action of progesterone on luteal cell viability is controversial. In fact, some studies have shown that progesterone is able to decrease $\mathrm{Bcl}-2$ concentrations, exerting a pro-apoptotic action (Gompel et al., 2000). In contrast, Matsuo et al. (1997) showed an anti-apoptotic action of progesterone in human uterine leiomyoma.

Members of the $\mathrm{Bcl}-2$ family may be of importance in 
controlling the rate of apoptosis (Bissonette et al., 1992; Yin et al., 1994); for example, Bcl-2 is known to protect cells from cell death. The activity of $\mathrm{Bcl}-2$ is determined by its interaction with Bax, a pro-apoptotic protein related to the $\mathrm{Bcl}-2$ family; thus, the relative ratio of $\mathrm{Bcl}-2$ to Bax expression, rather than the absolute concentrations, is the critical determinant for a cell to enter apoptosis.

Immunohistochemical (Rodger et al., 1995; Sugino et al., 2000) and biochemical studies (Vega et al., 2000) have shown that Bcl-2 and Bax are present in human corpus luteum. Rodger et al. (1995) reported that the expression of the product of the proto-oncogene $b c /-2$ remains unchanged throughout the luteal phase, but Sugino et al. (2000a) reported that $b c /-2$ mRNA concentrations were highest in the corpus luteum during the midluteal phase, and that bax mRNA concentrations were highest in the late human corpus luteum. Members of the Bcl-2 family, via dimeric interactions with other molecules that regulate cell death (Monney et al., 1996; Zou et al., 1997; Hu et al., 1998), are important for regulating activation of members of the caspase family (Alnemri et al., 1996), which serve as regulators and effectors of apoptosis (Thornberry, 1997; Thornberry et al., 1997). Many members of the caspase family are expressed in the ovary (Maravei et al., 1997), including in the human corpus luteum, where caspase-3 has been reported to be abundantly expressed, and thus it has been speculated that this protease is important for luteal regression (Krajewska et al., 1997). Nevertheless, little is known regarding the function of caspases in the human corpus luteum.

The mechanisms of regulation of the function of the human corpus luteum during the midluteal phase were investigated by studying the effect in vitro of IGF-I and IGFBP-3 on progesterone, oestradiol, androstenedione and testosterone production, and on the transcription of $\mathrm{Bcl}-2$ family genes related to apoptosis, such as bcl-2 and bax, in human corpora lutea obtained during the midluteal phase.

\section{Materials and Methods}

All chemicals were purchased from Sigma Chemical Co. (St Louis, MO); culture media were obtained from Gibco BRL Life Technologies (Grand Island, NY). Human recombinant IGF-I was obtained from NHPP, NIDDK and A. F. Parlow (National Hormone and Peptide Program, Torrance, CA), and IGFBP-3 was obtained from Research Diagnostic Inc. (Flanders, NJ). Progesterone, oestradiol, androstenedione and testosterone concentrations were measured by radioimmunoassay from Diagnostic System Laboratories (Webster, TX) and the concentration of LH was measured by radioimmunoassay from Diagnostic Products Corporation (Los Angeles, CA). Primers, DNase I (Amp Grade), TRIzol, SuperScript RT II, and Taq DNA Polymerase were purchased from Gibco BRL Life Technology (Bethesda, MD). Apoptosis was detected by the fluorescein kit (Promega, Madison, WI). Monoclonal anti-active caspase 3 (mAb C92-265) was obtained from PharMingen (San Diego,
CA), and the second antibody and reagents for the detection system were obtained from Dako Corp. (Carpinteria, CA).

\section{Subjects}

Corpora lutea were obtained from seven women aged $35.6 \pm 1.34$ years (range 31-40 years) with regular menstrual cycles, with a high parity, undergoing mini-laparotomy for tubal sterilization at the San Borja Arriarán Clinical Hospital, University of Chile (National Health Service, Santiago, Chile). None of the patients had experienced infertility or endometriosis, or had received any hormone therapy during the previous 3 months. The patients gave their written informed consent to participate in this study, which was approved by the Hospital Ethics Committee. The date of the cycle of each woman was confirmed by several criteria, including biopsies of the corpora luteal and endometrium (Noyes et al., 1950; Corner, 1956), ultrasonography, occurrence of the preovulatory LH peak and progesterone serum concentrations. The corpora lutea classified as midluteal were obtained 5-9 days after ovulation $(n=7)$; serum progesterone concentrations $($ mean \pm SEM) in the midluteal phase were $30.5 \pm 6.9 \mathrm{nmol}$ $\mathrm{I}^{-1}$. The preovulatory $\mathrm{LH}$ peak serum concentration fluctuated between $21.9 \mathrm{iu} \mathrm{I}^{-1}$ and $56.6 \mathrm{iu} \mathrm{I}^{-1}$ (first International Reference Preparation number 68/40).

\section{Tissue preparation}

After removal from the ovary, the corpora lutea were collected in sterile PBS and transported immediately to the laboratory at room temperature. One piece of each corpus luteum was immediately placed in $4 \%(\mathrm{w} / \mathrm{v})$ formalin and PBS for histological evaluation (Corner, 1956). The rest of the tissue was cut into slices (15-60 mg wet mass). Two or three slices from each corpus luteum (explants) for each experimental condition (basal, IGF-I or IGFBP-3) were incubated separately.

\section{Incubation procedures}

Tissue slices were incubated as reported by Vega et al. (2000). In brief, slices of corpus luteum from the midluteal phase were incubated with Hank's media, supplemented

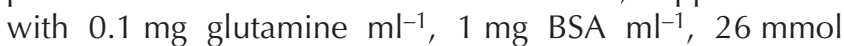
$\mathrm{NaHCO}_{3} \mathrm{I}^{-1}, 25 \mathrm{mmol}$ Hepes $\mathrm{I}^{-1}$, antibiotics (60 iu penicillin $\mathrm{ml}^{-1}$ and $5 \mathrm{mg}$ streptomycin $\left.\mathrm{ml}^{-1}\right)(\mathrm{pH} 7.4)$, to give a final volume of $0.5 \mathrm{ml}$. Basal and treated conditions (3.2-6.4 nmol IGF-I $\mathrm{I}^{-1}$ and 6.9-13.8 nmol IGFBP-3 I-1) were carried out in duplicate. Incubations were terminated at $4 \mathrm{~h}$ and the media were stored at $-20^{\circ} \mathrm{C}$ until assay for progesterone, oestradiol, androstenedione and testosterone by specific radioimmunoassay. After incubation, one tissue slice was stored at $-70^{\circ} \mathrm{C}$ for expression studies of mRNA for bcl-2, bax, $P_{450 \text { arom }}$ and $\beta$-actin, and another slice was fixed and embedded in paraffin wax for immunohistochemical identification of caspase 3 and for in situ detection of cell death. 


\section{Radioimmunoassay}

Progesterone and oestradiol concentrations were determined as described by Iñiguez et al. (2001) and the intra-assay and interassay coefficients of variation (CV) determined in the culture medium were, respectively, for progesterone: 3.8 and 5.5\%; and for oestradiol: 4.1 and $6.7 \%$. Androstenedione and testosterone were determined using commercial kits (DSL) and intra-assay and interassay CVs determined in culture medium were, respectively, for androstenedione: 3.2 and $6.1 \%$; and for testosterone: 6.2 and $8.1 \%$.

\section{Immunohistochemical study}

The immunohistochemical study for caspase 3 was performed in duplicate on human corpora lutea from the midluteal phase. Tissue sections $(5-6 \mu \mathrm{m})$ were deparaffinized in xylene, hydrated in 100, 95, 85, 70 and 50\% ethanol. Endogenous peroxidase activity was inhibited using 3\% (w/v) hydrogen peroxide for $15 \mathrm{~min}$, and then sections were blocked with PBS-2\% (w/v) BSA for $60 \mathrm{~min}$. The primary antibody for caspase 3 (applied at 1:100 dilution) is a purified anti-active caspase 3 monoclonal antibody that recognizes the active form of caspase 3 in human and mouse cells (Thornberry and Lazebnik, 1998). After incubation for $1 \mathrm{~h}$ at $37^{\circ} \mathrm{C}$, the second antibody, a biotinylated anti-mouse-anti-rabbit-anti-goat mixture immunoglobin, was applied for $30 \mathrm{~min}$. The reaction was evaluated by streptavidin-biotin peroxidase conjugate using 3,3'diaminobenzidine (DAB) as the chromogen, and cell nuclei were stained with haematoxylin. PBS-1\% (w/v) BSA was used instead of the primary antibody for the negative control, and no specific immunoreactivity was detected in these sections. The slides were analysed in a Nikon optical microscope (Nikon Inc., Melville, NY).

\section{RNA preparation, $c D N A$ synthesis and $R T-P C R$ assessment}

Total RNA was extracted from frozen corpora lutea from the midluteal phase, which were incubated in the absence (basal condition) or in the presence (treated conditions) of IGF-I or IGFBP-3. The extraction procedure of mRNA and the method of cDNA synthesis were those described by Johnson et al. (1997). A PCR fragment of 383 bp was generated with primers based on sequences 1894-1914 upstream (5'-AGG ATT GTG GCC TTC TTT GAG-3') and 2276-2256 downstream (5'-CCT GCA GCT TTG TTT CAT GGT-3') of a human follicular lymphoma bcl-2 cDNA (Tsujimoto and Croce, 1986). Another PCR fragment of 334 bp was generated with primers based on sequences 39-56 upstream (5'-CAC CAG CTC TGA GCA GAT-3') and 373-356 downstream (5'-CAG CCT TGA GCA CCA GTT$3^{\prime}$ ) of a human $\varepsilon$ bax cDNA (NIDig 4558699). Amplification was performed by adding $2 \mu \mathrm{l}$ cDNA to a total volume of $25 \mu$ PCR buffer containing $3 \mathrm{mmol} \mathrm{MgCl}_{2} \mathrm{I}^{-1}, 0.625 \cup \mathrm{Taq}$ DNA polymerase, and $0.25 \mu \mathrm{mol} \mathrm{I}^{-1}$ of each primer. $b c \mathrm{l}-2$ and bax were confirmed to correspond to human genes by direct sequencing using an ABI PRISM 310 analysis system (Perkin Elmer). The amplified fragments for $P_{450 a r o m}$ and reaction conditions were as described by Vega et al. (2000). A fragment of 260 and 661 bp of $\beta$-actin were amplified under the same conditions as described above to act as an internal control. Both $b c l-2$ and bax cDNA amplifications were repeated for 30 cycles and $\beta$-actin and $P_{450 \text { arom }}$ CDNA amplifications for 25 cycles, as described by Vega et al. (2000). All gene amplifications were within the linear range. CDNA synthesis and PCR variability were checked using control RNA with the respective control primers, as indicated by the manufacturer (Gibco BRL). The concentrations of bcl-2, bax, $P_{450 \text { arom }}$ and $\beta$-actin obtained for RT-PCR (semi-quantitative assay) were evaluated by computerized analysis of absorbance of the gel using Kodak 1D Image Analysis Software (Eastman Kodak Co., Rochester, NY).

In situ detection of apoptosis by terminal deoxynucleotidyl transferase (TdT)-mediated dUTP nickend labelling (TUNEL) method

Nuclear DNA fragmentation was performed as described by Vega et al. (2000). In brief, sections of corpora lutea from the midluteal phase, $5-6 \mu \mathrm{m}$ in thickness, were mounted on silane-coated slides, deparaffinized with xylene and rehydrated, and TdT-mediated dUTP nick-end labelling (TUNEL) was performed using the apoptosis detection fluorescein kit, according to the specifications of the manufacturer. Slides were analysed by fluorescence microscopy with a wide band excitation barrier filter suitable for analysing both green (fluorescein-labelled fragmented DNA) and red (propidium iodide counterstain identifying cell nuclei) fluorescence. The different optical fields (magnification $\times 400$ ) were selected randomly, and at least 2000 cells were counted for each sample. Positive control tissues were rat breast carcinoma and corpora lutea samples pretreated with DNase (5 $\mu \mathrm{g} \mathrm{ml}^{-1}$, type I). Negative controls (sections treated without the TdT enzyme) were included in all assays to estimate non-specific binding and auto fluorescence. Necrosis was not observed as assessed by morphological criteria.

\section{Statistical analysis}

The data are presented as mean \pm SEM and the results were analysed using the non-parametric test of ANOVA and the Newman-Keuls multiple comparison test. Differences were considered significant at $P<0.05$.

\section{Results}

Effect of IGF-I or IGFBP-3 on progesterone production in human corpus luteum from the midluteal phase

Explants of human corpus luteum from the midluteal phase were cultured for $4 \mathrm{~h}$ with or without different 
Table 1. Effect of insulin-like growth factor I (IGF-I) or IGF-binding protein 3 (IGFBP-3) on progesterone and oestradiol concentrations in culture media of explants of human corpora lutea during the midluteal phase

\begin{tabular}{lcl}
\hline Addition $\left(\mathrm{nmol} \mathrm{I}^{-1}\right)$ & Progesterone & \multicolumn{1}{c}{ Oestradiol } \\
\hline Basal & $14.1 \pm 2.1(15)$ & $267.8 \pm 24.6(15)$ \\
IGF-I (3.2) & $23.9 \pm 2.9(12)^{\mathrm{a}}$ & $297.7 \pm 65.3(13)$ \\
IGF-I (6.4) & $35.06 \pm 3.19(14)^{\mathrm{ab}}$ & $441.0 \pm 60.0(14)^{\mathrm{C}}$ \\
IGFBP-3 (6.9) & $5.4 \pm 0.5(4)^{\mathrm{a}}$ & $250.9 \pm 40.9(5)$ \\
IGFBP-3 (13.8) & $6.5 \pm 0.5(8)^{\mathrm{a}}$ & $156.1 \pm 21.9(8)^{\mathrm{a}}$ \\
\hline
\end{tabular}

Values are expressed as nmol per $g$ of corpus luteum \pm SEM.

Value in parentheses is the number of explants studied in five basal corpora lutea, five corpora lutea treated with IGF-I and in four corpora lutea treated with IGFBP-3.

a $P<0.01$ versus corresponding basal values; ${ }^{b} P<0.001$ versus IGF-I $\left(3.2 \mathrm{nmol} \mathrm{I}^{-1}\right) ;{ }^{c} P<0.05$ versus corresponding basal condition.

concentrations of IGF-I or IGFBP-3 to determine whether IGF-I or IGFBP-3 had an effect on luteal progesterone production. In the presence of IGF-I, progesterone production by explants of human corpus luteum from the midluteal phase increased by $69.5 \pm 0.9 \%$ with 3.2 nmol IGF-I I-1 $(P<0.01)$ and by $148.6 \pm 0.16 \%$ with 6.4 nmol IGF-I I-1 $(P<0.01)$ compared with basal values (Table 1$)$. Progesterone production in the presence of $6.4 \mathrm{nmol}$ IGF-I $\mathrm{I}^{-1}$ was significantly higher than it was with $3.2 \mathrm{nmol}$ IGF-I $\mathrm{I}^{-1}(P<0.01)$, indicating a dose-dependent stimulatory action of IGF-I on progesterone production by luteal explants. In contrast, IGFBP-3 elicited a decrease in progesterone production of $61.7 \pm 0.2 \%$ with $6.9 \mathrm{nmol}$ IGFBP-3 $\mathrm{I}^{-1}$ and of $53.9 \pm 0.2 \%$ with 13.8 nmol IGFBP-3 $\mathrm{I}^{-1}$ (Table 1, $P<0.01)$.

\section{Effect of IGF-I or IGFBP-3 on oestradiol production in human corpus luteum from the midluteal phase}

Explants of human corpus luteum from the midluteal phase were cultured for $4 \mathrm{~h}$ with or without different concentrations of IGF-I or IGFBP-3 to determine whether IGF-I or IGFBP-3 had an effect on luteal oestradiol production. An increase of $64.7 \pm 16.35 \%$ in oestradiol concentration was observed with 6.4 nmol IGF-I $\left.\right|^{-1}$ compared with basal values $(P<0.05)$, whereas no stimulatory effect was observed with a lower dose of IGF-I (Table 1). However, oestradiol concentration decreased $41.7 \pm 6 \%(P<0.01)$ in the presence of $13.8 \mathrm{nmol}$ IGFBP-3 $\mathrm{I}^{-1}$, and no effect was observed with $6.9 \mathrm{nmol}$ IGFBP-3 $\mathrm{I}^{-1}$ (Table 1).

\section{Effect of IGF-I or IGFBP-3 on androstenedione and testosterone production and on $\mathrm{P}_{450 \text { arom }}$ expression in human corpus luteum from the midluteal phase}

Explants from human corpora lutea from the midluteal phase were cultured for $4 \mathrm{~h}$ with or without IGF-I $(6.4 \mathrm{nmol}$ $\left.\mathrm{I}^{-1}\right)$ or IGFBP-3 $\left(13.8 \mathrm{nmol} \mathrm{I}^{-1}\right)$ to determine whether these substances had an effect on luteal androstenedione and testosterone production or on $P_{450 \text { arom }}$ gene expression. No significant effects of IGF-I or IGFBP-3 were observed on androstenedione (basal: $0.84 \pm 0.3 \mathrm{nmol}$ per $\mathrm{g}$ of corpus luteum) or testosterone production (basal: $2.8 \pm 0.9 \mathrm{nmol}$ per g of corpus luteum). Similarly, expression of normalized $P_{450 \text { arom }}$ mRNA was not changed significantly in the presence of IGF-I (1.29 \pm 0.09 arbitrary units) or IGFBP-3 (1.5 \pm 0.13 arbitrary units) compared with basal values (1.29 \pm 0.26 arbitrary units).

\section{Expression of caspase 3 in human corpus luteum from the midluteal phase}

The presence of caspase 3 was detected in human corpus luteum from the midluteal phase (Fig. 1a). Positive cells for active caspase 3 , indicated by abundant punctuate cytoplasmic staining, were observed within the parenchyma of all corpora lutea examined. In addition, some luteal cells of the stroma were weakly stained and endothelial cells displayed negative staining. Sections for negative control were free from staining (Fig. 1b).

\section{Effect of IGF-I and IGFBP-3 on bcl-2 and bax gene expression in human corpus luteum from the midluteal phase}

Explants from human corpora lutea from the midluteal phase were cultured for $4 \mathrm{~h}$ with or without IGF-I $(6.4 \mathrm{nmol}$ $\left.\mathrm{I}^{-1}\right)$ or IGFBP-3 $\left(13.8 \mathrm{nmol}^{-1}\right)$ to determine whether these substances had an effect on expression of $b c /-2$ and bax mRNA. The expression of bcl-2 mRNA was increased by IGF-I by approximately $200 \%(P<0.05)$, whereas in the presence of IGFBP-3, bcl-2 mRNA expression was similar to the basal condition (Fig. 2a). Expression of bax was not modified by the action of IGF-I, but IGFBP-3 induced a significant increase in bax mRNA expression during culture $(P<0.05)$ (Fig. 2b). Accordingly, the ratio of $b c l-2$ to bax mRNA expression increased significantly by $150 \%$ in the presence of IGF-I $(P<0.05)$, whereas a $50 \%$ decrease was observed in the presence of IGFBP-3 (Fig. 2c).

\section{Effect of IGF-I and IGFBP-3 on apoptosis in human corpus luteum from the midluteal phase}

The TUNEL method was used to detect the percentage of cells from human corpora lutea from the midluteal phase with apoptotic positive signals. This percentage decreased $43 \pm 8.3 \%$ in the presence of $6.4 \mathrm{nmol} \mathrm{IGF-I} \mathrm{I}^{-1}$ and increased $140 \pm 14.5 \%$ in the presence of $13.8 \mathrm{nmol}$ IGFBP-3 $\mathrm{I}^{-1}$, compared with basal values $(P<0.05)$ (Fig. 3).

\section{Discussion}

Maximum steroidogenic activity in the corpus luteum occurs during the midluteal phase and a gradual decline in steroid synthesis represents the involution period of the tissue. Luteal regression is necessary for the cyclicity of the reproductive process, and occurs by the synchronous loss of cellular function and subsequent cell death by apoptosis. 

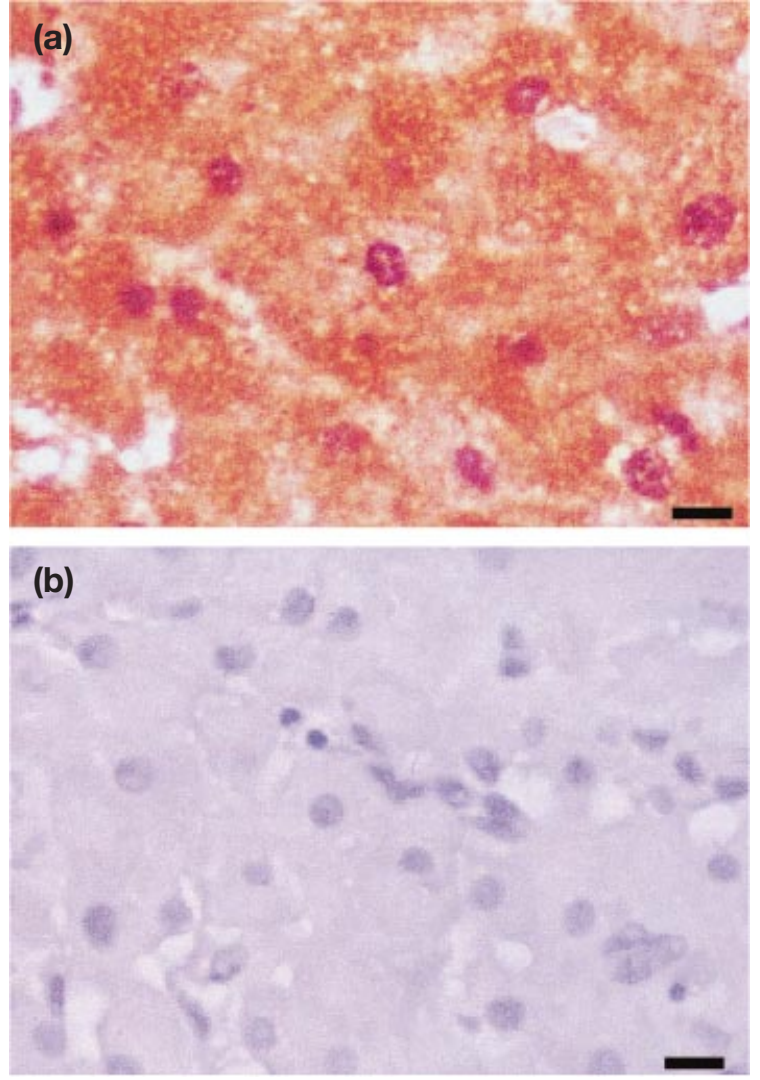

Fig. 1. Immunohistochemical staining for caspase 3 in explants of human corpus luteum from the midluteal phase. (a) Representative corpus luteum explants with positive immunostaining for caspase 3 protein in paraffin wax sections of three corpora lutea from the midluteal stage. (b) Negative control. Scale bars represent $30 \mu \mathrm{m}$.

This process is triggered by the activation of a proteolytic cascade of cysteine aspartate-specific proteases, namely caspases, and caspase 3 is the main downstream effector of cell death (Boone and Tsang, 1998). The results of the present study showed a high expression of active caspase 3 in corpus luteum from the midluteal phase, indicating that the active enzyme is important for luteal regression and that programmed cell death may be triggered during the midluteal phase, as proposed by Vega et al. (1994b).

The components of the IGF-IGFBP system are expressed in the human corpus luteum and play a role in the regulation of its lifespan (Iñiguez et al., 2001). The present results indicate that IGF-I, a multifunctional monomeric peptide, regulates the steroidogenic function in human corpus luteum during the midluteal phase, increasing progesterone and oestradiol production. Párrizas and Loroith (1997) suggested that IGF-I acts as a cell survival factor and inhibits apoptosis in a number of types of cell through modulation of the activity of Bcl-2 family members, with the concomitant regulation of the apoptotic mechanism in most cells (O'Connor et al., 2000). The protective action of Bcl-2 in cells is determined by its interaction with Bax, a pro-apoptotic gene; the ratio of bcl-2 to bax expression, rather than

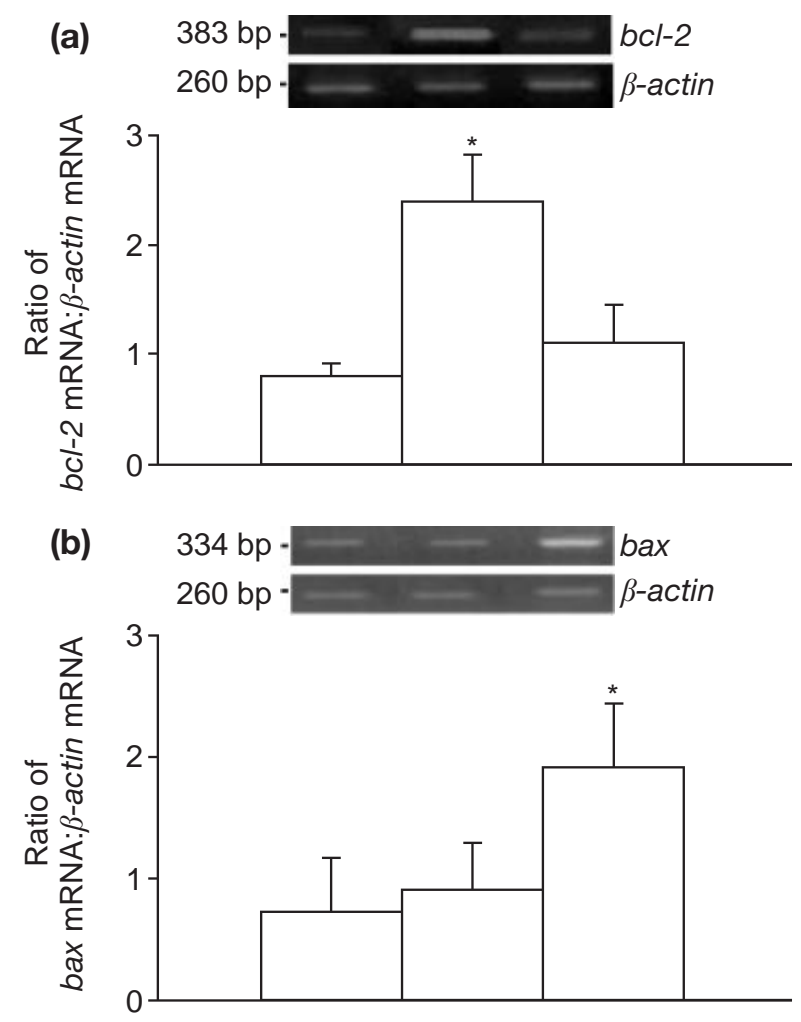

(c)

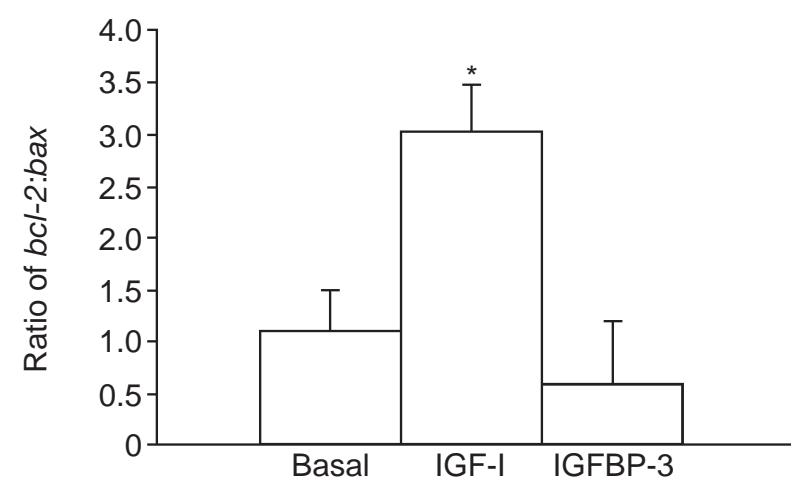

Fig. 2. Effect of insulin-like growth factor I (IGF-I) or IGF-binding protein 3 (IGFBP-3) on bcl-2 and bax mRNA expression in human corpus luteum from the midluteal phase. Normalized yield of (a) bcl-2 and (b) bax PCR fragments relative to $\beta$-actin PCR products. (c) Relative ratio of bcl-2 to bax mRNA expression in human corpus luteum from the midluteal phase. Tissue explants were incubated for $4 \mathrm{~h}$ without (basal: bcl-2, three corpora lutea, $n=4$ slices; bax, four corpora lutea, $n=7$ slices) or with IGF-I (bcl-2, three corpora lutea, $n=5$ slices; bax, two corpora lutea, $n=3$ slices) or IGFBP-3 (bcl-2, two corpora lutea, $n=4$ slices; bax, two corpora lutea, $n=2$ slices). The ratio of $b c l-2$ to bax was calculated from each sample in (a) and (b). ${ }^{*} P<0.05$ compared with basal values.

the absolute concentration, is the critical determinant of cell fate. These reports are in agreement with the results obtained in the present study indicating that IGF-I facilitates cell survival in corpus luteum during the midluteal phase, 


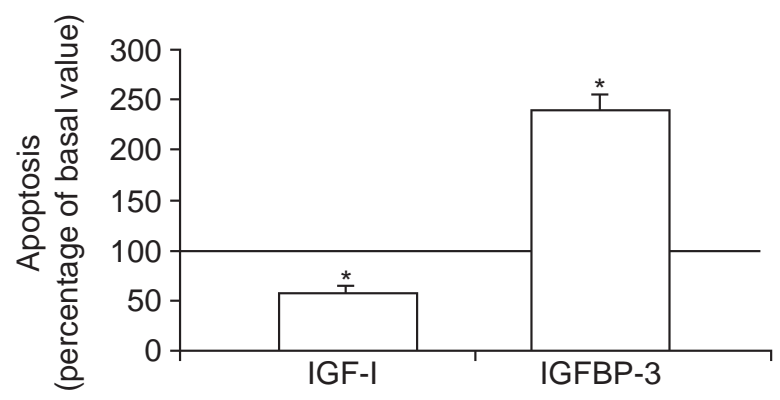

Fig. 3. Apoptotic cell death in situ was assesssed using terminal deoxynucleotidyl transferase-mediated dUTP nick-end labelling (TUNEL) in human corpus luteum from the midluteal phase in the presence of insulin-like growth factor I (IGF-I) or IGF-binding protein 3 (IGFBP-3). Tissue explants obtained from human corpora lutea from the midluteal phase $(n=5)$ were incubated for $4 \mathrm{~h}$ in the presence of 6.4 nmol IGF-I I-1 or $13.8 \mathrm{nmol}$ IGFBP-3 $\mathrm{I}^{-1}$. Values are expressed as percentage \pm SEM of positive green fluorescence luteal cells (a mean of 2000 cells counted for each corpus luteum). $* P<0.05$ compared with basal values.

mainly by a positive action on $b c l-2$ gene expression. Even though the expression studies were performed using RT-PCR, a semi-quantitative technique, this finding is consistent with data showing that, in the presence of 6.4 nmol IGF-I $\mathrm{I}^{-1}$, the number of luteal cells undergoing apoptosis decreases in corpus luteum from the midluteal phase. These results indicate that there is a relationship between bcl-2 expression and apoptosis in corpus luteum during the midluteal phase. It will be important to determine the mechanism by which IGF-I sustains the expression of $b c l-2$ in the human corpus luteum during the midluteal phase.

IGFBP-3 is the principal carrier of IGF-I in the circulation and the primary regulator of the amount of free IGF-I available to interact with the IGF-I receptor. IGFBP-3 is produced in large amounts by the human corpus luteum during its lifespan (Iñiguez et al., 2001). However, there is accumulating evidence that IGFBP-3 can also cause apoptosis in a manner that is independent of IGF (Grimberg, 1999). The results obtained in the present study showed that addition of $6.4 \mathrm{nmol}$ IGFBP-3 $\mathrm{I}^{-1}$ reduced progesterone and oestradiol production and increased the percentage of cells with apoptotic positive signals, coincident with the increase in bax gene expression, which is elicited by IGFBP-3. These results indicate that IGFBP-3 inhibits the protective action of endogenous IGF-I, although a potential IGF-I-independent action of IGFBP-3 on luteal cell viability cannot be ruled out.

One of the mechanisms involved in the enhancement or diminution of oestradiol production in human corpus luteum by IGF-I and IGFBP-3 may be attributable to an effect on the transcription of the cytochrome $P_{450 \text { arom }}$. $P_{450 \text { arom }}$ mRNA is expressed in human corpora lutea of different ages and exhibits a decreased profile throughout the luteal phase (Vega et al., 2000). Nevertheless, it is possible that aromatase activity was affected in the experimental system used in the present study. Addition of $6.4 \mathrm{nmol}$ IGF-I $\mathrm{I}^{-1}$ or $13.8 \mathrm{nmol}$ IGFBP-3 $\mathrm{I}^{-1}$ did not affect $P_{450 a r o m}$ gene expression in corpus luteum from the midluteal phase; however, IGF-I increased, and IGFBP-3 decreased, oestradiol production. In this regard, it is probable that the incubation period used in the experimental model of the present investigation did not allow visualization of an effect of IGF-I and IGFBP-3 on aromatase RNA expression. However, in human corpus luteum from the midluteal phase, other stimuli have been shown to regulate the expression of $P_{450 \text { arom }}$ mRNA in the same experimental system (Vega et al., 2000). These findings raised the question of whether locally produced IGFBPs can affect cell response to IGF-I.

Furthermore, production of androstenedione and testosterone, which are $\mathrm{P}_{450 \text { arom }}$ substrates, was not changed by the action of IGF-I and IGFBP-3. Therefore, in the experimental model used in the present study, the increase in oestradiol production probably reflects the stimulatory action of IGF-I upstream of the steroidogenic pathway, in the conversion of cholesterol to pregnenolone and the concomitant increase in progesterone synthesis. Steroidogenic acute regulatory (StAR) protein stimulates the translocation of cholesterol from the outer to the inner mitochondrial membrane, and IGF-I is known to stimulate StAR mRNA and protein expression in human granulosalutein cells (Devoto et al., 1999).

In conclusion, the results of the present study indicate that IGF-I and IGFBP-3 act as regulatory peptides of human corpus luteum function during the midluteal phase. This action may be direct or mediated by the regulation of progesterone and oestradiol synthesis or by the expression of genes related to cell survival, such as bcl-2 and bax. Collectively, this information provides knowledge about the various regulatory mechanisms of human corpus luteum from the midluteal phase. A better understanding of the molecules that regulate corpus luteum function at the time of implantation may contribute to future studies of recurrent pregnancy loss of unknown aetiology.

The authors are grateful to A. Castro (School of Medicine, University of Chile) for helping in immunohistochemical studies; D. Vantman and A. Cortinez (National Health Service, Chile) for their role in recruitment and surgical procedures of subjects; A. Estévez (Postgraduate PLACIRH Fellow, University of Chile) for helping with RT-PCR technics; B. Angel (Postgraduate Student, University of Chile) for helping with radioimmunoassays; and M. Maliqueo (MSc, University of Chile) for helping with statistical analysis. The authors also wish to thank E. Simpson (Center for Reproductive Biology Sciences, University of Texas, and SouthWestern Medical Center at Dallas, TX) for the generous gift of $\mathrm{P}_{450 \text { arom }}$ probe; and the women who donated tissue. This work was supported by FONDECYT 1980899 and PLACIRH 232/99-2000.

\section{References}

Alnemri ES, Livingston DJ, Nicholson DW, Salvesen G, Thornberry NA, Wong WW and Yuan J (1996) Human ICE/CED-3 protease nomenclature Cel/ 8171 
Bissonnette RP, Echeverri F, Mahboubi A and Green DR (1992) Apoptotic cell death induced by c-myc is inhibited by bcl-2 Nature 359 552-554

Boone DL and Tsang BK (1998) Caspase-3 in the rat ovary: localization and possible role in follicular atresia and luteal regression Biology of Reproduction 58 1533-1539

Brannstrom M, Friden BE, Jasper M and Norman RJ (1999) Variations in peripheral blood levels of immunoreactive tumor necrosis factor alpha (TNFalpha) throughout the menstrual cycle and secretion of TNFalpha from the human corpus luteum European Journal of Obstetrics and Gynecology and Reproductive Biology 83 213-217

Bukovsky A, Caudle MR, Keenan JA, Wimalasena J, Upadhyaya NB, Van Meter SE (1995) Is corpus luteum regression an immune-mediated event? Localization of immune system components and luteinizing hormone Biology of Reproduction 53 1373-1384

Carrasco I, Troncoso JL, Devoto L and Vega M (1996) Differential steroidogenic response of human luteal cell subpopulations Human Reproduction 13 1584-1589

Corner GW (1956) The histological dating of corpus luteum of menstruation American Journal of Anatomy 98 377-394

Devoto L, Kohen P, Castro O, Vega M, Troncoso JL and Charreau EM (1995) Multihormonal progesterone synthesis in cultured human midluteal cells Journal of Clinical Endocrinology and Metabolism 80 $1566-1570$

Devoto L, Christenson LK, McAllister JM, Makrigiannakis A and Strauss JF (1999) Insulin and insulin-like growth factor-I and -II modulate human granulose-lutein cell steroidogenesis: enhancement of steroidogenic acute regulatory protein (StAR) expression Molecular Human Reproduction 5 1003-1010

Dews M, Prisco M, Peruzzi F, Romano G, Morrione A and Baserga R (2000) Domains of the insulin-like growth factor I receptor required for the activation of extracellular signal-regulated kinases Endocrinology 141 1289-1300

Drop SL, Schuller AG, Lindenbergh-Kortleve DJ, Groffen C, Brinkman A and Zwarthoff EC (1992) Structural aspects of the IGFBP family Growth Regulation 2 69-79

Gompel A, Somai S, Chaouat M, Kazem A, Kloosterboer HJ, Beusman I, Forgez P, Mimoun M and Rostene W (2000) Hormonal regulation of apoptosis in breast cells and tissues Steroids 65 593-598

Grimberg A (1999) P53 and IGFBP-3: apoptosis and cancer protection Molecular Genetics and Metabolism 70 85-98

Hu Y, Benedict MA, Wu D, Inohara N and Núñez G (1998) Bcl-XL interacts with Apaf-1 and inhibits Apaf-1-dependent caspase-9 activation Proceedings National Academy of Sciences USA 95 4386-4391

Iñiguez G, Villavicencio A, Gabler F, Palomino A and Vega M (2001) Effect of nitric oxide on the expression of insulin-like growth factors and insulin-like growth factor binding proteins throughout the lifespan of the human corpus luteum Reproduction 122 865-873

Johnson MC, Devoto L, Retamales I, Kohen P, Troncoso JL and Aguilera G (1996) Localization of insulin-like growth factor (IGF-I) and IGF-I receptor expression in human corpora lutea: role on estradiol secretion Fertility and Sterility 65 489-494

Johnson MC, Vega M, Vantman D, Troncoso JL and Devoto L (1997) Regulatory role of angiotensin II on progesterone production by cultured human granulosa cells. Expression of angiotensin II type-2 receptor Molecular Human Reproduction 3 663-668

Johnson MC, Diaz HA, Stocco C, Palomino A, Devoto L and Vega M (1999) Antisteroidogenic action of nitric oxide on human corpus luteum in vitro: mechanism of action Endocrine 11 31-36

Krajewska M, Wang H-G, Krajewski S, Zapata JM, Shabaik A, Gascoyne R and Reed JC (1997) Immunohistochemical analysis of in vivo patterns of expression of CPP32 (Caspase-3), a cell death protease Cancer Research 57 1605-1613

Lei ZM, Chegini N and Rao ChV (1991) Quantitative cell composition of human and bovine corpora lutea from various reproductive states Biology of Reproduction 44 1148-1156

Maravei DV, Trbovich AM, Perez GI, Tilly KI, Banach D, Talanian RV, Wong WW and Tilly JL (1997) Cleavage of cytoskeletal proteins by caspases during ovarian cell death: evidence that cell-free systems do not always mimic apoptotic events in intact cells Cell Death and Differentiation 4 707-712

Matsuo H, Maruo T and Samoto T (1997) Increased expression of Bcl-2 protein in human uterine leiomyoma and its upregulation by progesterone Journal of Clinical Endocrinology and Metabolism 82 293-299

Monney L, Otter I, Olivier R, Ravn U, Mirzasaleh H, Fellay I, Poirier GG and Borner C (1996) Bcl-2 overexpression blocks activation of the death protease CPP32/Yama/apopain Biochemical and Biophysical Research Communications $221340-345$

Morales MP, Galvez A, Eltit JM, Ocaranza P, Diaz Araya G and Lavandero S (2000) IGF-I regulates apoptosis of cardiac myocyte induced by osmotic stress Biochemical and Biophysical Research Communications 270 1029-1035

Noyes RW, Hertig AT and Rock J (1950) Dating the endometrial biopsy Fertility and Sterility 1 3-12

O'Connor R, Fennelly C and Krause D (2000) Regulation of survival signals from the insulin-like growth factor-I receptor Biochemical Society Transactions 28 47-51

Párrizas M and Leroith D (1997) Insulin-like growth factor-1 inhibition of apoptosis is associated with increased expression of the $b c l-x L$ gene product Endocrinology $\mathbf{1 3 8} 1355-1358$

Razandi M, Pedram A and Levin ER (2000) Estrogen signals to the preservation of endothelial cell form and function Journal of Biological Chemistry 27538 540-38 546

Remacle Bonnet MM, Garouste FL, Heller S, Andre F, Marvaldi JL and Pommier GJ (2000) Insulin-like growth factor I protects colon cancer cells from death factor-induced apoptosis by potentiating necrosis factor alpha-induced mitogen-activated protein kinase and nuclear factor kappa B signaling pathway Cancer Research 60 2007-2017

Rodger FE, Fraser HM, Duncan WC and Illingworth PJ (1995) Immunolocalization of bcl-2 in the human corpus luteum Human Reproduction $101566-1570$

Rodger FE, Fraser HM, Krajewski S and Illingworth PJ (1998) Production of the proto-oncogene BAX does not vary with changing in luteal function in women Molecular Human Reproduction 4 27-32

Rotello RJ, Lieberman RC, Lepoff RB and Gerschenson LE (1992) Characterization of uterine epithelium apoptotic cell death kinetics and regulation by progesterone and RU 486 American Journal of Pathology $140449-456$

Shikone T, Yamoto M, Kokawa K, Yamashita K, Nishimori K and Nakano R (1996) Apoptosis of human corpora lutea during cyclic luteal regression and early pregnancy Journal of Clinical Endocrinology and Metabolism 81 2376-2380

Sugino N, Suzuki T, Kashida S, Karube A, Takiguchi S and Kato H (2000) Expression of $\mathrm{Bcl}-2$ and $\mathrm{Bax}$ in the human corpus luteum during the menstrual cycle and in early pregnancy: regulation by human chorionic gonadotropin Journal of Clinical Endocrinology and Metabolism 85 4379-4386

Tenniswood MP, Guenette RS, Lakins J, Mooibroek M, Wong P and Welsh JE (1992) Active cell death in hormone-dependent tissues Cancer Metastasis Review 11 197-220

Thornberry NA (1997) The caspase family of cysteine proteases British Medical Bulletin 53 478-490

Thornberry NA and Lazebnik Y (1998) Caspases: enemies within Science 281 1312-1316

Thornberry NA, Rosen A and Nicholson DW (1997) Control of apoptosis by proteases Advances in Pharmacology 41 155-77

Tsujimoto Y and Croce CM (1986) Analysis of the structure, transcripts, and protein products of bcl-2, the gene involved in human follicular lymphoma Proceedings National Academy of Sciences USA 83 5214-5218

Vega M, Devoto L, Castro O and Kohen P (1994a) Progesterone synthesis by human luteal cells: modulation by estradiol Journal of Clinical Endocrinology and Metabolism 79 466-469

Vega M, Castillo T, Retamales I, Las Heras J, Devoto L and Videla LA (1994b) Steroidogenic capacity and oxidative stress-related parameters in human luteal cell regression Free Radical Biology and Medicine $\mathbf{1 7}$ 493-499 
Vega M, Carrasco I, Castillo T, Troncoso JL, Videla LA and Devoto L (1995) Functional luteolysis in response to hydrogen peroxide in human luteal cells Journal of Endocrinology 147 177-182

Vega M, Urrutia L, Iñiguez G, Gabler F, Devoto L and Johnson MC (2000) Nitric oxide induces apoptosis in the human corpus luteum in vitro. Molecular Human Reproduction 6 681-687

Yin XM, Oltvai ZN and Korsmeyer SJ (1994) BH1 and BH2 domains of Bcl2 are required for inhibition of apoptosis and heterodimerization with Bax Nature 369 321-323
Zou H, Henzel WJ, Liu X, Lutschg A and Wang X (1997) Apaf-1, a human protein homologous to $C$. elegans CED-4, participates in cytochrome c-dependent activation of caspase-3 Cel/ 90 405-413

Received 6 February 2002.

First decision 9 April 2002.

Revised manuscript received 17 May 2002.

Accepted 18 June 2002. 